
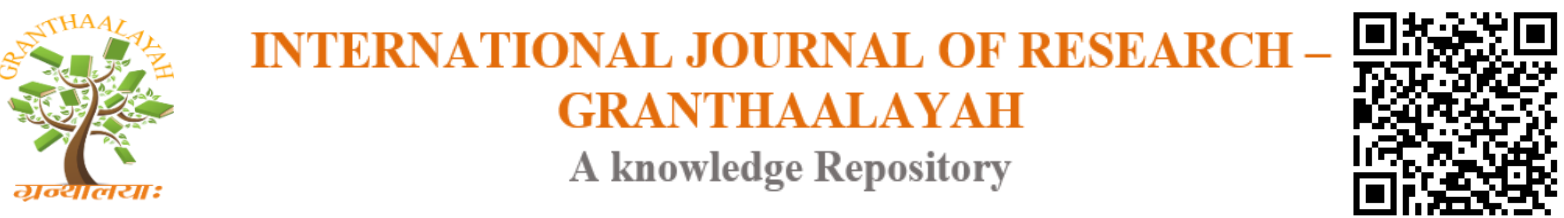

Science

\title{
DEVELOPMENT OF A COMPOSITE OF POLY-E-CAPROLACTONE- CERIUM OXIDE
}

\author{
Alejandra Melissa Martínez-Hernández ${ }^{1}$, Simón Yobanny Reyes-López ${ }^{* 2}$ \\ 1 , *2 Departamento de Ciencias Químico Biológicas, Instituto de Ciencias Biomédicas \\ Universidad Autónoma de Ciudad Juárez, México
}

\begin{abstract}
Nanotechnology is used in a variety of sectors for the manufacture of materials. However, there is a risk from exposure to nanomaterials due to their chemical composition and processing form, giving rise to health risks. $\mathrm{CeO} 2$ particles present antioxidant properties that accelerate the wound poly- $\varepsilon$-caprolactone (PCL) provides the property of biocompatibility and biodegradability of the material. For the regulation of the transport and release of cerium oxide particles was incorporated into a polymeric matrix composed of PCL. Therefore, in this study we propose the elaboration of a composite material of poly- $\varepsilon$-caprolactone-cerium by the electrospinning technique. Electrospinning for example has been widely used to fabricate scaffolds imitating the structure of natural extracellular matrix. The fibers obtained with an average diameter of $600 \mathrm{~nm}$ was characterized by confocal microscopy, scanning electron microscopy, infrared spectroscopy, Differential thermal analysis, Thermogravimetric Analysis and Differential Scanning Calorimetry. Additionally, genotoxic effect was evaluated by comet assay in Vicia faba cell nuclei, results show that the material made has no genotoxic effects in Vicia faba cells.
\end{abstract}

Keywords: Electrospinning; Fibers; Oxide de Cerium; Poly-E-Caprolactone; Comet Assay.

Cite This Article: Alejandra Melissa Martínez-Hernández, and Simón Yobanny Reyes-López. (2017). "DEVELOPMENT OF A COMPOSITE OF POLY-E-CAPROLACTONE-CERIUM OXIDE." International Journal of Research - Granthaalayah, 5(7), 493-505. https://doi.org/10.29121/granthaalayah.v5.i7.2017.2158.

\section{Introduction}

Nanomaterials have an important impact on society; they are used in diverse fields by the properties they present, such as high surface area, greater hardness, elasticity, and electrical conductivity, etc. These unique characteristics plus the functionalities from the polymers themselves impart nanofibers with many desirable properties for advanced applications ${ }^{[1]}$.

However, there is a risk from exposure to nanoparticles that occurs mainly by inhalation, ingestion and contact whit the skin ${ }^{[2]}$. Alternatively, it is possible to regulate the transport and 
release of nanoparticles from a polymer matrix, resulting in the formation of a composite by unifying and potentiate the properties of both components ${ }^{[3]}$. Composite are of interest to several industries due to their attractive properties, research has been interested on composite materials to optimize their processing parameters as well as optimize their mechanical behavior and reliability. Although composite is possible to provide excellent mechanical, chemical and biological properties, only incorporating nanoparticles ${ }^{[1-3]}$.

Electrospinning technique is a method used to obtain polymer fibers whose diameter is less than $100 \mathrm{~nm}$. It uses a high voltage electric field to form a stream of polymeric fluid. Electrospinning process is performed by applying high voltage to a polymer filled capillary which will flow whit the aid of a pump and an electrode, the resulting fibers are collected in a grounded plate (collector). As the electric field strength increases, the semispherical surface of the fluid at the tip of the capillary tube takes a conical shape known as a Taylor cone. The parameters and processing variables that affect the electrospinning method, are molecular weight, distribution, architecture and process parameters as distance from the collector and environmental conditions (temperature and humidity). Fibers have been successfully applied in various fields such as medicine, information and communication, certain drugs, textiles, agriculture and food, etc., ${ }^{[1-4]}$. Cerium oxide $\left(\mathrm{CeO}_{2}\right)$ is a non-cytotoxic oxide-metal powder that exhibits beneficial properties for humans, predominating its antioxidant capacity, that allows accelerating wound healing by sequestering excess superoxide radicals in cells and thus decreasing the chronic inflammation [5,6]. By decreasing the excess reactive oxygen species (ROS) in the cells, avoids the alteration of cellular functionalities contributing to the decrease of degenerative diseases as: cancer, neurological diseases, cardiovascular, diabetes and chronic inflammatory conditions such as rheumatoid arthritis ${ }^{[7,8]}$.

Poly-e-caprolactone (PCL) is a biodegradable, biocompatible linear aliphatic polyester, bioresorbable, and non-toxic polymer widely used in the biomedical area, tissue engineering, skin regeneration, scaffolding support for fibroblasts and growth of osteoblasts in systems of continuous bone repair ${ }^{[2,6]}$. Pharmaceutical industry uses polymer biocompatibility matrices as delivering systems for active principles. This methodology allows the fabrication of membranes for biomedical use as biological tissue regeneration for dressings, environmental remediation and water treatment ${ }^{[2,7,8]}$.

Single cell gel electrophoresis assay (SCGE) commonly known as comet assay is a method for the evaluation of induced DNA damage in individual cells ${ }^{[9]}$. It has been used in various areas, including biological control human, genotoxicology, ecological monitoring and as a tool for research on DNA damage or repair in different cell types, in response to exposure of genotoxic substances (UV and oxidative damage). This assay has been applied in organisms such as bean plants "Vicia faba", polychaeta "Nereis virens", worms "Eisenia. foetida", mussels "Mytilus edulis", oysters "Crasosstrea virginica", fish "Onchorynchus mykiss", frogs "Rana clamitans" y mice "Mus musculus" for research on DNA damage in response to exposure of genotoxic substances ${ }^{[10,11,12]}$. This study proposes the elaboration of a Poly-E-caprolactone-cerium (PCL$\mathrm{CeO}_{2}$ ) composite material using the electrospinning technique. This material would allow transport and release of cerium oxide particles by incorporating them into a polymer matrix composed of poly- $\mathcal{E}$-caprolactone, unifying and potentializing the properties of both materials. 
Another goal of this study was to characterize the microstructure and genotoxic properties of the structured poly- $\varepsilon$-caprolactone-cerium composite.

\section{Materials and Methods}

Preparation of solutions of PCL

$100 \mathrm{~mL}$ of a $10 \%$ PCL polymer solution $(\mathrm{P} / \mathrm{V})$ were prepared using acetone as the solvent. 10 $\mathrm{mL}$ of the prepared solution were deposited in 10 vials. then a was performed 1:1 dilution of acetone with nonionic surfactant by adding to 5 vials $1 \mathrm{~mL}$ of this solution for each $10 \mathrm{~mL}$ of PCL solution, mixed and sonicated for $30 \mathrm{~min}$.

Preparation of solutions of $\mathrm{PCL}-\mathrm{CeO}_{2}$

$\mathrm{CeO}_{2}$ powders whit a particle size $<250 \mathrm{~nm}$ were deposited at different concentrations: $0.25,0.5$, 1 and $1.5 \%$, in the 5 vials with $10 \mathrm{~mL}$ of the $10 \%$ PCL solution without nonionic surfactant, mixed and sonicated for $30 \mathrm{~min}$. In a second batch the $\mathrm{CeO}_{2}$ powders were deposited at the different established in 5 vials with $10 \mathrm{~mL}$ of the $10 \%$ PCL; $1 \mathrm{~mL}$ of a nonionic surfactant was added to each solution (1:1), mixed and sonicated for $30 \mathrm{~min}$.

\section{Obtaining of fibers by technique electrospinning}

Polymer solutions of $10 \%$ PCL and PCL-CeO ${ }_{2}$ at different concentrations $(0.25,0.5,1$ and $1.5 \%)$ with and without surfactant were subjected to electrospinning method, controlling the parameters of voltage, solution flow and distance between collector and needle.

\section{Characterization}

A characterization of the crystalline planes of the ceria was carried out using an X-ray diffractometer with a $\mathrm{Cu} \mathrm{K \alpha}$ radiation of $1,540 \mathrm{~nm}$, operating at $20 \mathrm{Kv}$ range from 5 to $80^{\circ}$. The morphologies of the PCL- $\mathrm{CeO}_{2}$ nanocomposites collected on carbon-coated copper grids were observed with a scanning electron microscopy (SEM, JEOLJSM-6400) operated at $20 \mathrm{kV}$. Before observation, the scaffolds were coated with platinum using a sputter coating. Fiber diameter was measured from the SEM micrographs. FTIR spectra were taken with an Alpha Platinum-ATR spectrometer and transmission spectra of the samples were obtained by forming fiber films. Differential Scanning Calorimetry was employed to study thermal behavior of asspun fibers. Phase transitions and weight loss from 20 to $1200^{\circ} \mathrm{C}$ were determined using a heating ramp of $10^{\circ} \mathrm{C} / \mathrm{min}$.

\section{Single cell gel electrophoresis assay}

For the determination of genotoxic damage caused by fibers PCL and PCL-CeO ${ }_{2}$ with and without surfactant were used single cell gel electrophoresis assay on bean cells (Vicia faba), using as protocol described by Gichner (2003). 60 beans (Vicia faba) were germinated in moist chambers for 4 days at $20^{\circ} \mathrm{C}$. Then $2 \mathrm{~cm}$ of the roots were cut and are introduced into $20 \mathrm{ml}$ of PBS ( $\mathrm{pH}=7.4)$, sealed and refrigerated at $4^{\circ} \mathrm{C}$ in the absence of light. For each treatment three seedlings of $V$. faba were selected, of which 7 cuts of approximately $10 \mathrm{~mm}$ were made from the root, omitting the meristem and distal regions; Cuts were performed in $250 \mu \mathrm{l}$ of $\mathrm{PBS}(\mathrm{pH}=7.4)$. $50 \mu \mathrm{L}$ of the cells were then taken and embedded in $50 \mu \mathrm{L} \mathrm{1 \%}$ low melting point agarose then 80 $\mu \mathrm{L}$ were taken and deposited in $50 \mu \mathrm{L}$ of $1 \%$ normal melting point agarose; then $1 \times 1 \mathrm{~cm}$ cuts of the PCL and $\mathrm{CeO}_{2}$ fibers were made at different concentrations of $\mathrm{CeO}_{2}(0.25,0.5,1$ and $1.5 \%)$ 
and exposed to $V$. faba cells incubating at $4{ }^{\circ} \mathrm{C}$ for $24 \mathrm{~h}$; for the positive control, $V$. faba cells directly exposed to potassium dichromate $\left(\mathrm{K}_{2} \mathrm{Cr}_{2} \mathrm{O}_{7}, 0.05 \mathrm{M}\right)$ were used for $2 \mathrm{~h}$; while intact cells were used for the negative control.

Each treatment was performed in duplicate; after $24 \mathrm{~h}$ of treatment, the cells were subjected to preincubation with electrophoresis buffer $(\mathrm{pH}=13)$ for $15 \mathrm{~min}$; then the electrophoresis was started at $0.74 \mathrm{~V} / \mathrm{cm}(25 \mathrm{~V}, 300 \mathrm{~mA})$ for 20 minutes at a temperature of $4{ }^{\circ} \mathrm{C}$; Neutralized with $0.4 \mathrm{M}$ Tris for $5 \mathrm{~min}$ (in triplicate), fixing the nuclei with $100 \%$ ethanol for $15 \mathrm{~min}$. The $1 \mathrm{x}$ ethidium bromide was finally used as the nucleic acid enhancer and then analyzed by epifluorescence microscopy (ZEISS ${ }^{\circledR}$ ), using a 515-560 nm excitation filter and a 590nm barrier filter.

\section{Results and Discussions}

The particle $\mathrm{CeO}_{2}$ was characterized by X-ray diffraction (Figure 1) obtaining characteristic diffraction peaks of the fluorite type cubic structure of cerium oxide, according to its JCPDS card number: 34-394 (Joint Committee on Powder Diffraction Standard) ${ }^{[13]}$.

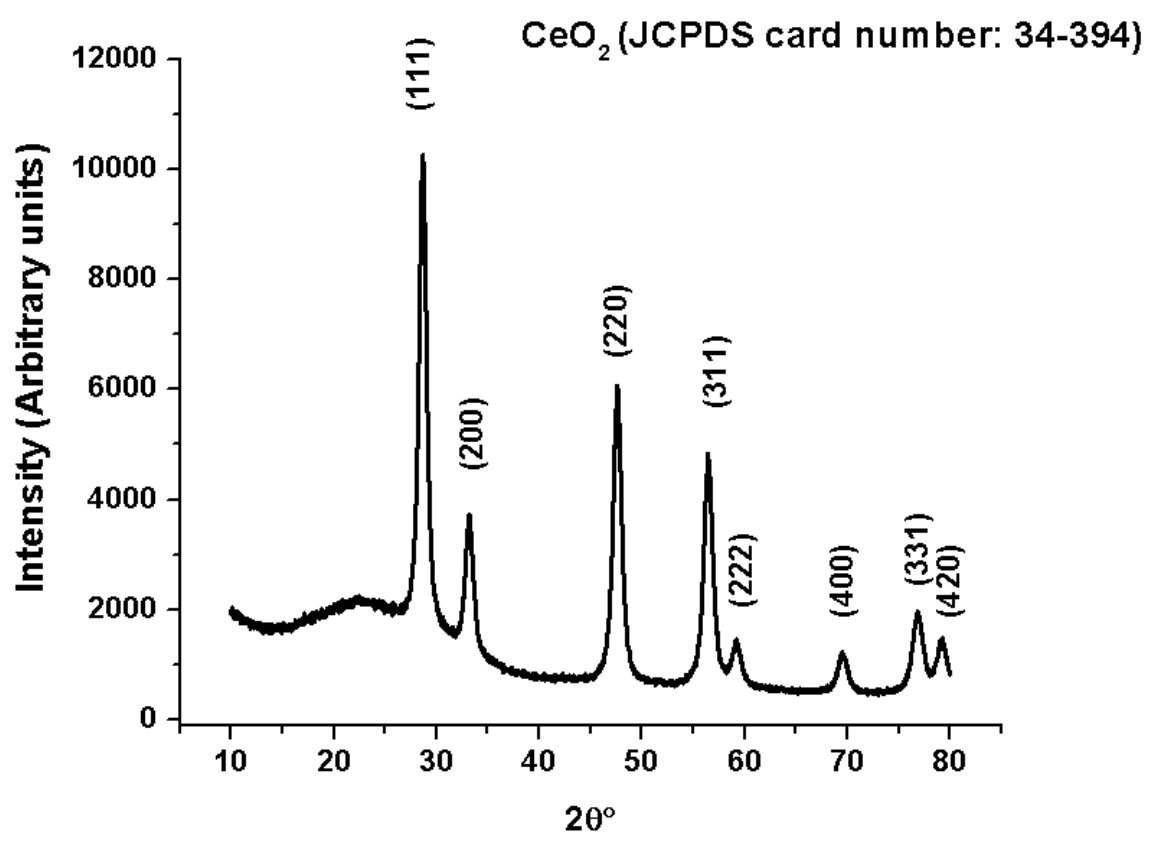

Figure 1: Diffractogram of the characteristic planes of the fluorite phase.

\section{PCL fibers with and without surfactant}

Table I shows the processing parameters and the obtained diameter of the PCL composite fibers with and without the use of the nonionic surfactant. When the surfactant was added, a larger diameter of fiber was obtained in comparison to fiber without surfactant. The diameter of fiber with surfactant was higher because the surface tension of the polymer solution decreased ${ }^{[14]}$. On the other hand, the processing parameters that influence in this case are the distance and the flow, to a greater distance and smaller flow, smaller fibers are obtained ${ }^{[15]}$. 
Table 1: Diameters and processing parameters of PCL fibers.

\begin{tabular}{|ccccccc|}
\hline $\mathbf{1 0 \%}$ PCL & Temperature $\left({ }^{\circ} \mathbf{C}\right)$ & $\begin{array}{c}\text { Humidity } \\
(\%)\end{array}$ & $\begin{array}{c}\text { Flow } \\
(\boldsymbol{\mu L} / \mathbf{m})\end{array}$ & $\begin{array}{c}\text { Voltage } \\
(\mathbf{k V})\end{array}$ & $\begin{array}{c}\text { Distance } \\
(\mathbf{c m})\end{array}$ & $\begin{array}{c}\text { *Diameter } \\
(\boldsymbol{\mu m})\end{array}$ \\
\hline without surfactant & 24 & 16 & 5 & 11 & 8 & $0.84 \pm 0.22$ \\
with surfactant & 22 & 31 & 20 & 11 & 20 & $1.09 \pm 0.46$ \\
\hline
\end{tabular}

*Diameter obtained from the Motic Images plus 2.0®; SD, standard deviation.

PCL- $\mathrm{CeO}_{2}$ fibers without surfactant

Table II shows the processing parameters as well the diameter of the fibers in the PCL-CeO 2 composite without the use of the nonionic surfactant. Smaller fibers were obtained by using a greater distance and a slower flow ${ }^{[15]}$.

Table 2: Diameters and processing parameters of PCL-CeO2 fibers without surfactant.

\begin{tabular}{|ccccccc|}
\hline $\begin{array}{c}\text { Concentration } \mathrm{CeO}_{2} \\
(\%)\end{array}$ & Temperature $\left({ }^{\circ} \mathbf{C}\right)$ & Humidity $(\%)$ & $\begin{array}{c}\text { Flow } \\
(\boldsymbol{\mu} \mathbf{L} / \mathbf{m})\end{array}$ & $\begin{array}{c}\text { Voltage } \\
(\mathbf{k V})\end{array}$ & Distance $(\mathbf{c m})$ & $\begin{array}{c}* \text { Diameter } \\
(\boldsymbol{\mu m})\end{array}$ \\
\hline 0.25 & 20 & 16 & 5 & 11 & 14.5 & $0.71 \pm 0.30$ \\
0.5 & 21 & 16 & 10 & 10 & 13.5 & $0.85 \pm 0.33$ \\
1 & 20 & 16 & 15 & 11 & 11.5 & $0.79 \pm 0.31$ \\
1.5 & 20 & 16 & 15 & 11 & 14 & $0.76 \pm 0.29$ \\
\hline
\end{tabular}

*Diameter obtained from the Motic Images plus 2.0®; SD, standard deviation.

PCL-CeO2 fibers with surfactant

Table III shows the processing parameters of the fibers with surfactant. Larger diameters are observed in comparison to the fibers obtained without the addition of the surfactant as shown in Figure 2. Nonionic surfactants contribute to the dispersion of ceramic suspensions, allowing the interface between a liquid and the particle to be controlled by improving the wetting property of the liquid ${ }^{[16]}$.

Table 3: Diameter of PCL-CeO2 fibers with use of surfactant.

\begin{tabular}{|ccccccc|}
\hline $\begin{array}{c}\text { Concentration } \mathbf{C e O}_{2} \\
(\%)\end{array}$ & $\begin{array}{c}\text { Temperature } \\
\left({ }^{\circ} \mathbf{C}\right)\end{array}$ & $\begin{array}{c}\text { Humidity } \\
(\boldsymbol{\%})\end{array}$ & $\begin{array}{c}\text { Flow } \\
(\boldsymbol{\mu} \mathbf{L} / \mathbf{m})\end{array}$ & $\begin{array}{c}\text { Voltage } \\
(\mathbf{k V})\end{array}$ & $\begin{array}{c}\text { Distance } \\
(\mathbf{c m})\end{array}$ & $\begin{array}{c}\text { *Diameter } \\
(\boldsymbol{\mu m})\end{array}$ \\
\hline 0.25 & 19 & 16 & 15 & 11 & 14 & $0.82 \pm 041$ \\
0.5 & 19 & 16 & 15 & 11 & 14 & $1.41 \pm 0.81$ \\
1 & 19 & 16 & 15 & 11 & 14 & $1.00 \pm 0.55$ \\
1.5 & 19 & 16 & 15 & 11 & 14 & $0.66 \pm 0.36$ \\
\hline
\end{tabular}

*Diameter obtained from the Motic Images plus 2.0®; SD, standard deviation. 


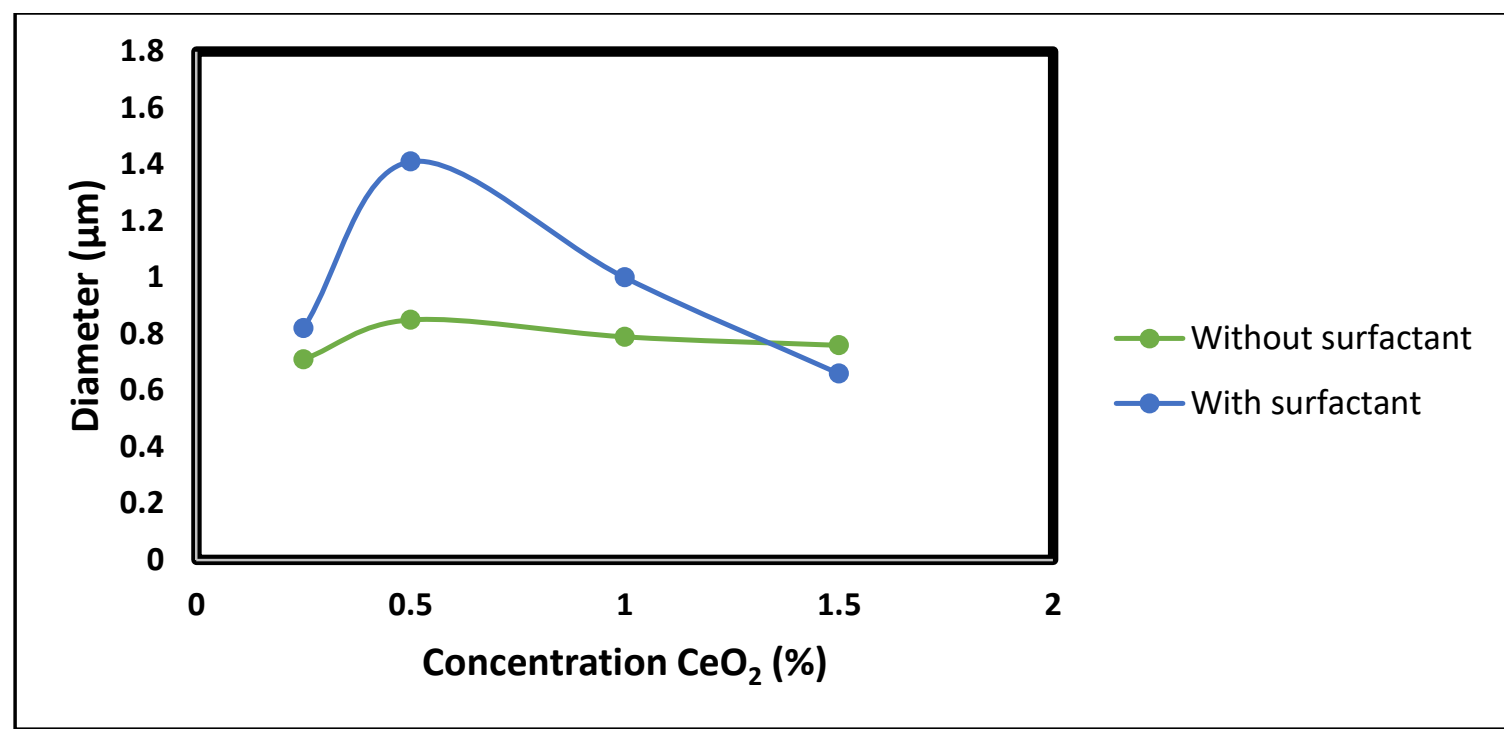

Figure 2: Diameter of PCL-CeO2 fibers, with and without addition of nonionic surfactant.

\section{Confocal microscopy}

In order to determine whether the particles were homogeneously distributed within the fiber, confocal microscopy images by fluorescence at $488 \mathrm{~cm}^{-1}$ were obtained. Micrographs revealed that the $\mathrm{CeO}_{2}$ particles at a concentration of $1.5 \%$ are distributed unevenly within the fibers, forming agglomerates (Figure 3a). While with surfactant, the particle $\mathrm{CeO}_{2}$ to $1.5 \%$ is evenly distributed within the fiber (Figure 3b).

Figure 4 a shows $\mathrm{CeO}_{2}$ particles at $0.025 \%$ are not homogeneously distributed within the fibers when the surfactant is not used. Figure $4 \mathrm{~b}$ shows that $\mathrm{CeO}_{2}$ particles are well distributed when the surfactant is used. The observed behavior is due to the decrease of the surface tension between PCL polymer molecules and particles of $\mathrm{CeO}_{2}$, causing the homogeneous dispersion of $\mathrm{CeO}_{2}$ in PCL fiber through Van der Waals interactions ${ }^{[17]}$.

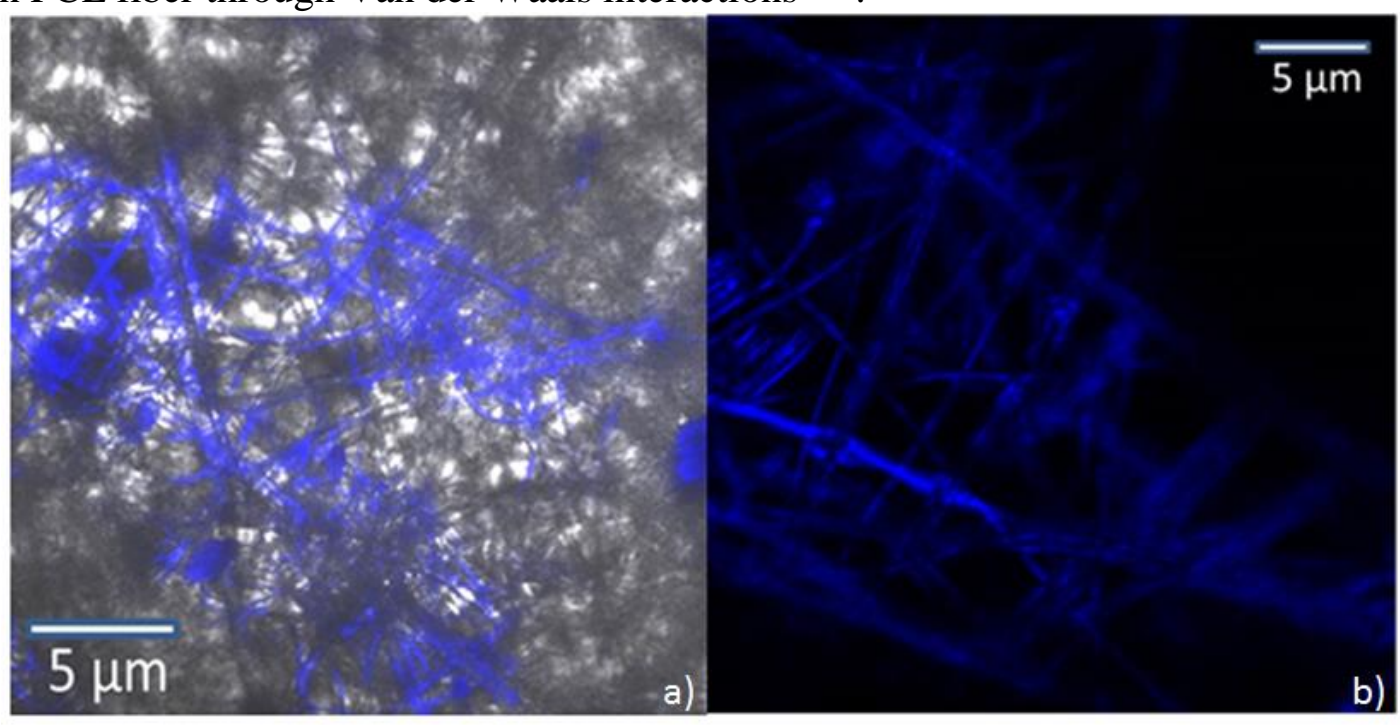

Figure 3: Micrographs at $600 \mathrm{X}$ of the fluorescence of $\mathrm{CeO} 2$ at $1.5 \%$ in fibers. a) without surfactant; b) with surfactant. 

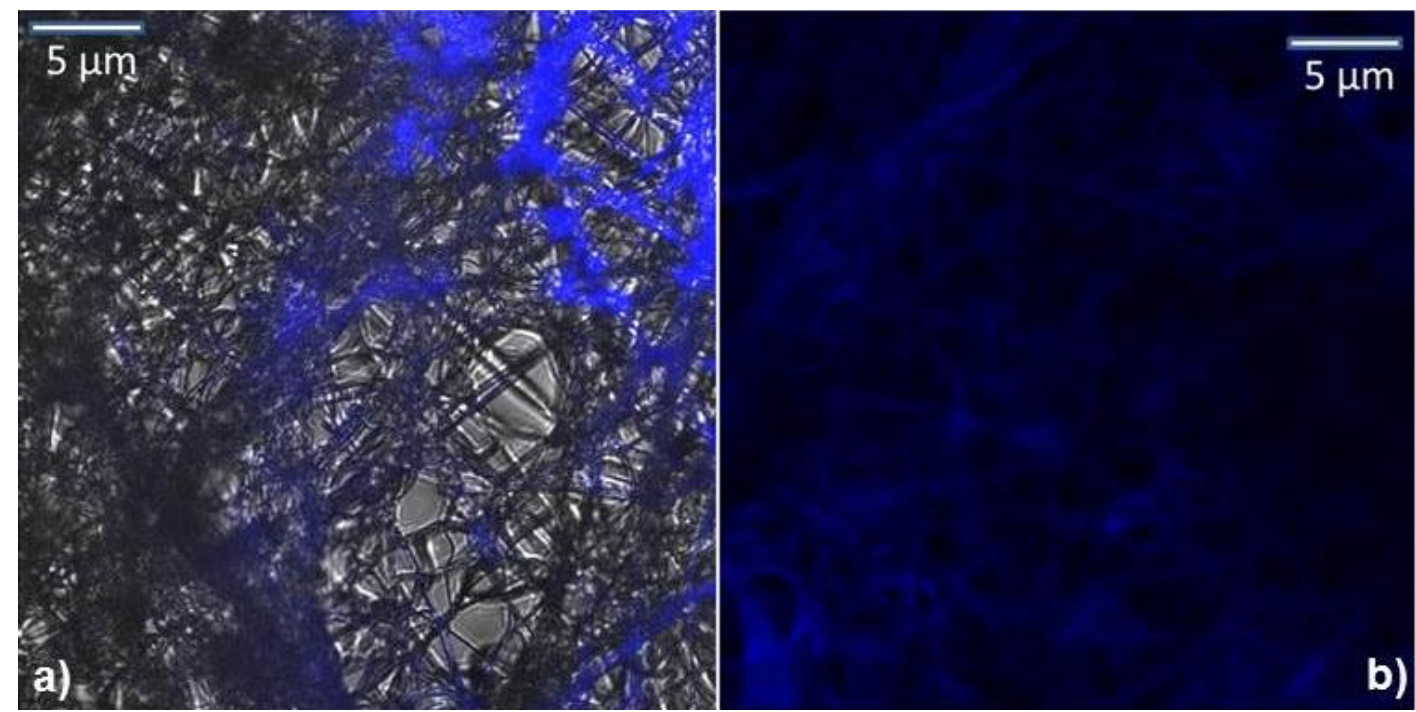

Figure 4: Micrographs at $600 \mathrm{X}$ of the fluorescence of $0.5 \% \mathrm{CeO} 2$ in fibers. a) without surfactant; b) with surfactant

Scanning electron microscopy (SEM).

SEM micrographs (at $2000 \mathrm{X}$ ) show the microstructure of the $\mathrm{PCL}-\mathrm{CeO}_{2}$ fiber without the use of surfactant. The distribution and shape of the PCL fiber as well as the dispersion of the $\mathrm{CeO}_{2}$ particle are not homogeneous (Figure $5 \mathrm{a}$ ). Figure $5 \mathrm{~b}$ shows a magnification of a $\mathrm{CeO}_{2}$ particles agglomerate $(10,000 \mathrm{X})$ within a PCL fiber.
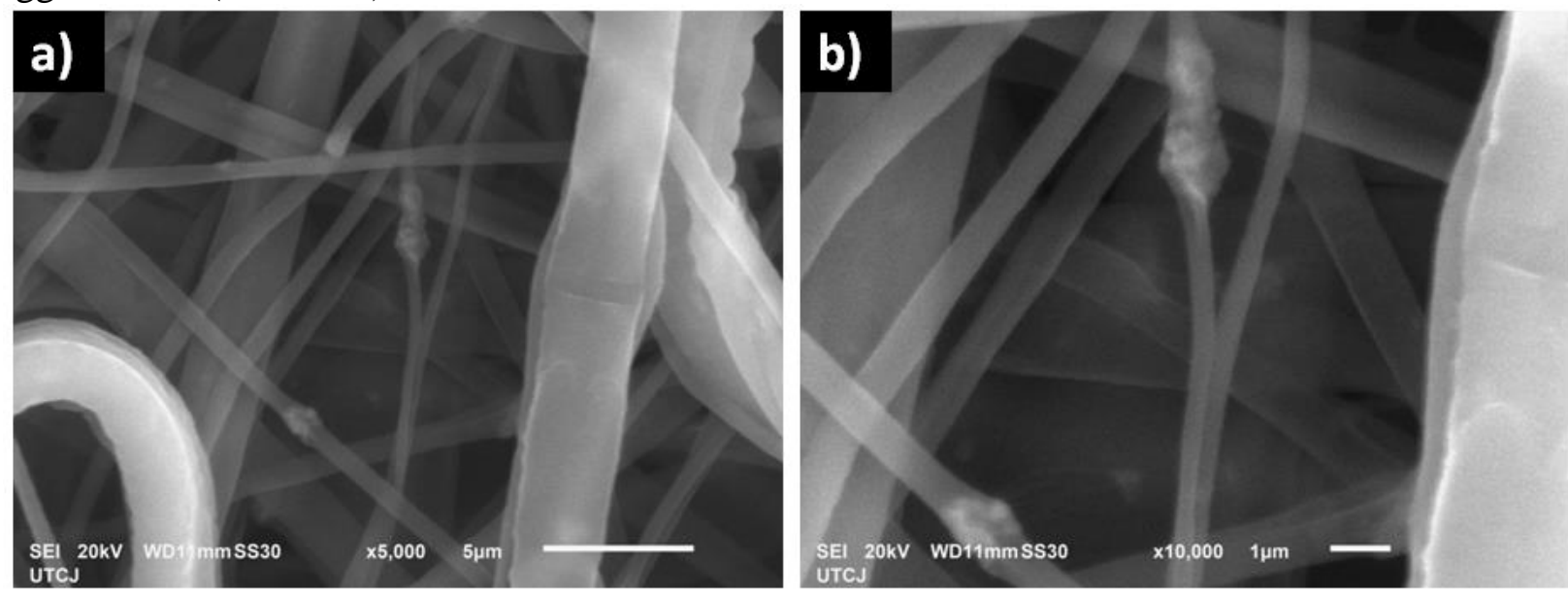

Figure 5: a) Micrograph of SEM at 2,000, microstructure of the PCL-CeO2 fiber and b) Micrograph at 10,000 of fluorescence $488 \mathrm{~cm}-1$ of a CeO2 agglomeration in the PCL fiber.

Infrared spectroscopy $(I R)$.

In Figure 6 a) characteristic bands of the $\mathrm{CeO}_{2}$ particle are observed, bands at 3417, 1632, and $1381 \mathrm{~cm}^{-1}$ are related to vibrations of absorbed water molecules, while the band at $533 \mathrm{~cm}^{-1}$ represents stretching vibrations of the union $\mathrm{Ce}-\mathrm{O}^{[18]}$. Figure $6 \mathrm{~b}$ ) shows the bands of the functional groups of the PCL. The band at $1727 \mathrm{~cm}^{-1}$ corresponds to stretching vibrations of the carbonyl group $(\mathrm{C}=\mathrm{O}) ; 1240 \mathrm{~cm}^{-1}$ band corresponds to asymmetric stretching vibrations of the ether group (C-O-C); $1190 \mathrm{~cm}^{-1}$ band corresponds to the stretching vibration of the ether linkage O-C-O; while the bands at $2949 \mathrm{~cm}^{-1}$ and $2865 \mathrm{~cm}^{-1}$ correspond to asymmetric and symmetrical 
stretching vibrations of the methylene group $\left(\mathrm{CH}_{2}\right)$, respectively. Finally, the band at $1293 \mathrm{~cm}^{-1}$ corresponds to stretching vibrations of the carbonyl $(\mathrm{C}-\mathrm{O})$ and alkane $(\mathrm{C}-\mathrm{C})$ groups ${ }^{[19]}$. The vibration-related characteristic bands of the PCL and $\mathrm{CeO} 2$ functional groups found in the PCL$\mathrm{CeO} 2$ fiber are shown in Figure $6 \mathrm{c}$.
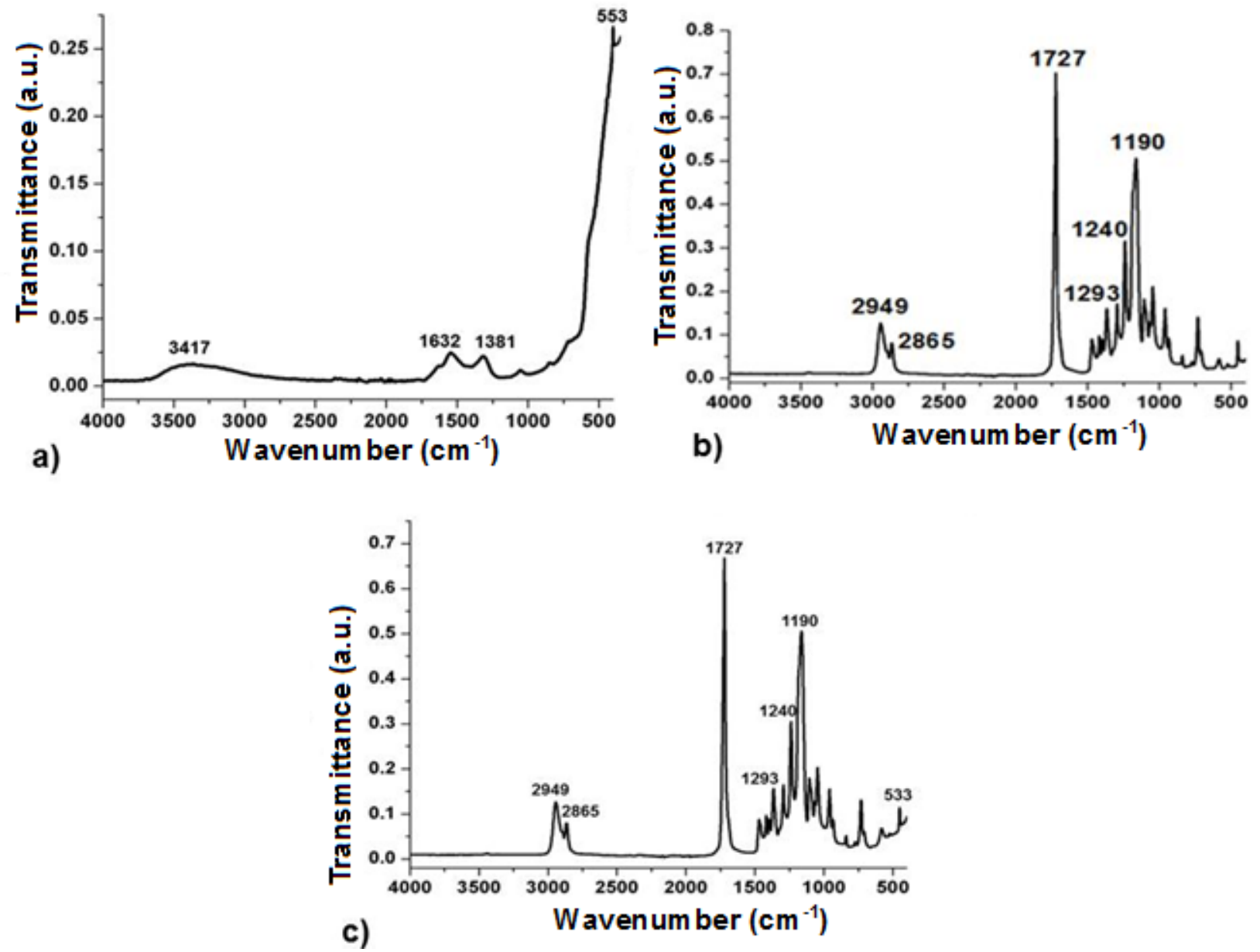

Figure 6: a) Infrared spectrum of the $\mathrm{CeO} 2$ particle, b) Infrared spectrum of PCL and c) Infrared spectrum of the PCL-CeO2 fiber.

Thermal analysis of the PCL and PCL-CeO fibers

Figure 7 and 8 show the differential thermal analysis (DTA), Differential Scanning Calorimetry (DSC), Thermogravimetric Analysis (TGA) and derived for PCL and PCL-CeO 2 . The peaks found between $64{ }^{\circ} \mathrm{C}$ and $417{ }^{\circ} \mathrm{C}$ in the DTA curve correspond to the melting of the polymer and to the loss of organic material from the polymer, with weight loss around $98 \%$ for PCL fibers and $82 \%$ for PCL-CeO $\mathrm{C}_{2}$. The increase in weight is possibly due to oxidation of residual carbon with increasing temperature. At temperatures above $600^{\circ} \mathrm{C}$, the fiber samples exhibit the same tendency, reflecting no transition in the observed thermograms ${ }^{[20]}$. 


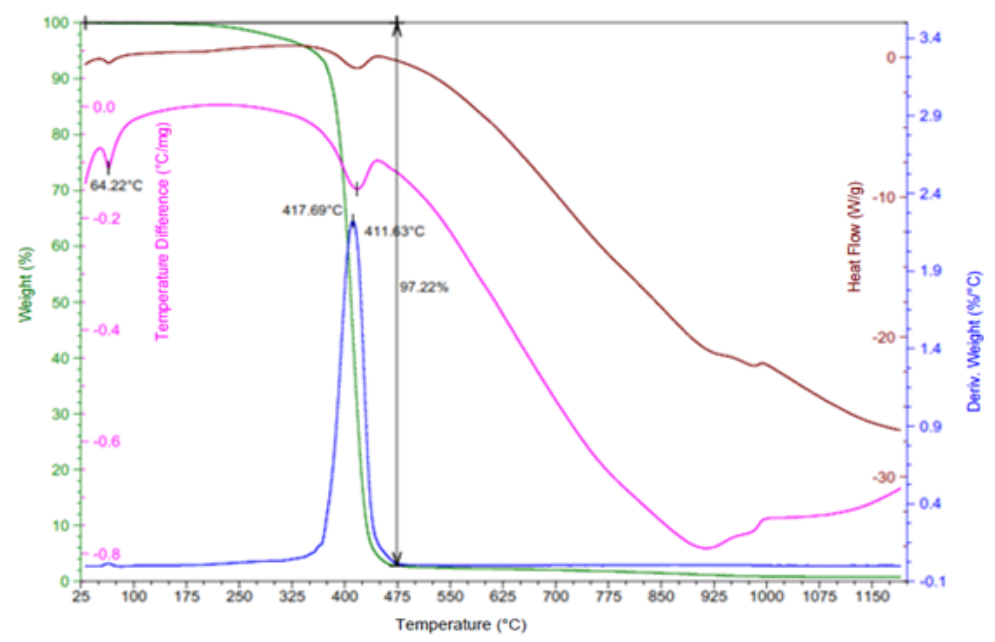

Figure 7: ATD, CDB and TGA for PCL fibers.

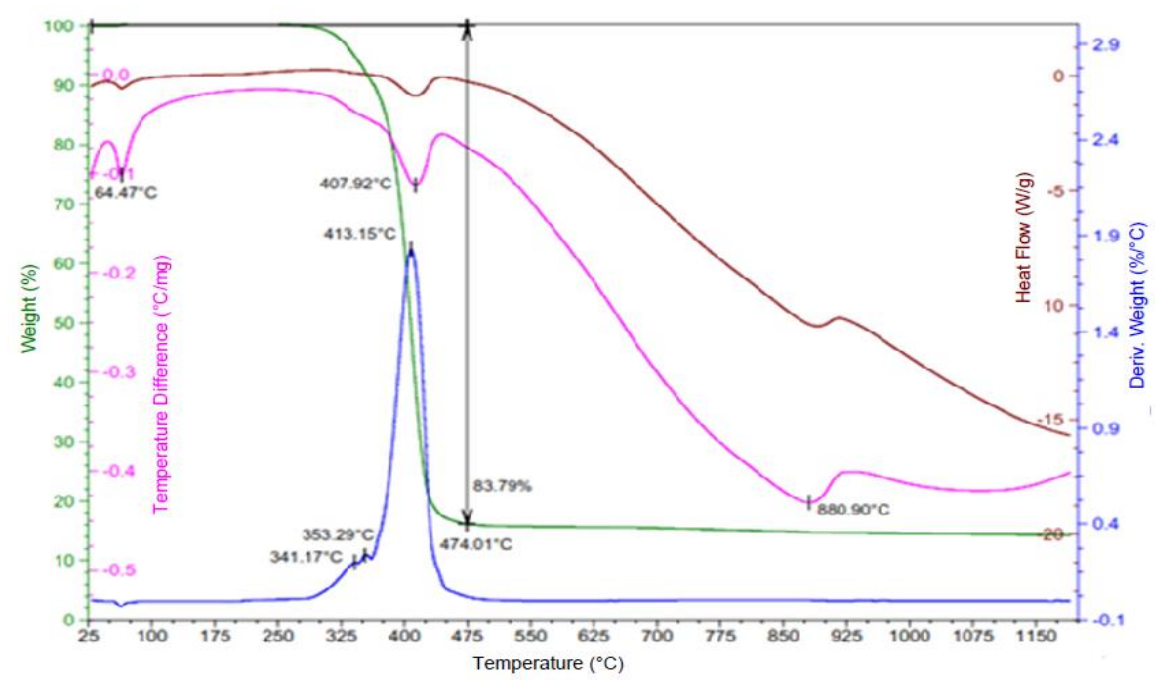

Figure 8: ATD, CDB and TGA for PCL- CeO2 fibers.

Single cell gel electrophoresis assay

Figures $9 \mathrm{a}$ and $9 \mathrm{~b}$ show the morphology of healthy $V$. faba nuclei and damaged nuclei (comet) by potassium dichromate $\left(\mathrm{K}_{2} \mathrm{Cr}_{2} \mathrm{O}_{7}\right)$, respectively. While Figures 9 (c) and 9 (d) make a comparison between the Tail Length of the damaged cores of $V$. faba by the exposure of PCL and PCL- $\mathrm{CeO}_{2}$ fibers at different concentrations $(0.25,0.5,1$ and $1.5 \%)$ and nuclei damaged by exposure to $\mathrm{K}_{2} \mathrm{Cr}_{2} \mathrm{O}_{7}$, respectively. 
a)
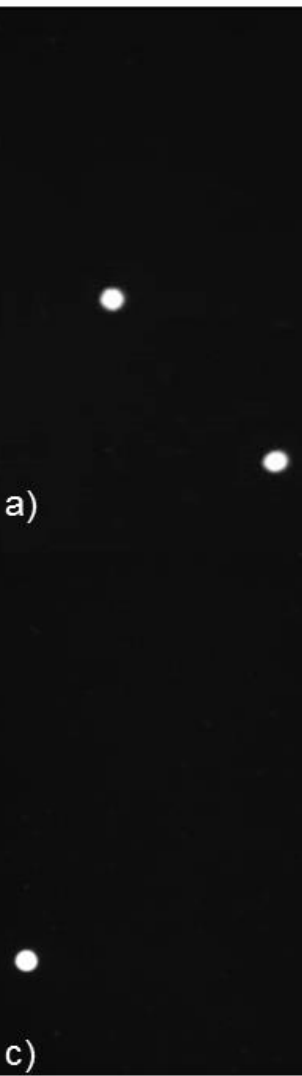

c) b)

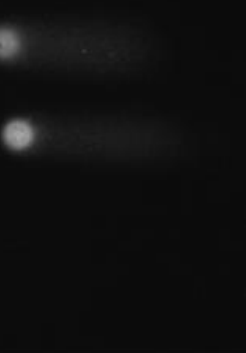

Figure 9: Micrograph at 20X of the morphology of V. faba nuclei. a) Healthy nuclei; b) Nuclei damaged by K2Cr2O7; c) Nuclei damaged by PCL and PCL-CeO2 fibers; d) Nuclei damaged by $\mathrm{K} 2 \mathrm{Cr} 2 \mathrm{O} 7$.

DNA damage (tail moment) of $V$. faba nuclei was quantified through Comet Assay IV ${ }^{\circledR}$ program (Table IV) the program measures the length of the tail caused by the chromatin damage. A kruskal-Wallis test $(\mathrm{P} \leq 0.05)$ was performed with the statistical program IBM SPSS Statistics 22. The analysis showed that the tail moment distribution is the same with respect to the negative control and treatments of $10 \%$ PCL and $\mathrm{PCL}-\mathrm{CeO}_{2}$ fibers whit surfactant at different concentrations of $\mathrm{CeO}_{2}$.

Table 4: Size of the tail moment of cells of Vicia faba.

\begin{tabular}{|l|l|l|}
\hline Treatments & $\begin{array}{l}* \text { Mean } \\
\text { Positive control }\end{array}$ & **SD \\
\hline Negative control & 7.00 & 1.544 \\
\hline $\begin{array}{l}\text { PCL 10\% + } \\
\text { PCe }\end{array}$ & 0.285 & 2.025 \\
\hline PCL 10\%+ $\mathrm{CeO}_{2} 0.5 \%$ & 0.202 & 0.320 \\
\hline PCL 10\%+ $\mathrm{CeO}_{2} 1 \%$ & 0.324 & 0.196 \\
\hline PCL 10\%+ $\mathrm{CeO}_{2} 1.5 \%$ & 0.519 & 1.381 \\
\hline PCL 10\% & 0.390 & 1.331 \\
\hline
\end{tabular}

Size of the tail moment obtained from the Comet Assay IV® program; ** SD, standard deviation. 
An increased DNA damage in $V$. faba cells is observed for $10 \%$ PCL fibers without $\mathrm{CeO}_{2}$ particles. Adding $\mathrm{CeO}_{2}$ particles diminishes the DNA damage. However, using a $1.5 \%$ concentration causes a damage similar to the fibers without $\mathrm{CeO}_{2}$ particles. The positive control presented greater damage compared to the fibers treatments of PCL and PCL-CeO 2 at different concentrations.

In order to corroborate the data Mann-Whitney test was performed. No significant differences between the negative control and the treatments of PCL and PCL-CeO $\mathrm{C}_{2}$ fibers at different concentrations were observed. A significant difference $10 \%$ PCL fibers and PCL-CeO $\mathrm{Fibers}_{\text {at }}$ concentrations of $0.25,0.5,1$, and $1.5 \%$ were found. A significant difference between the positive control and the fibers $10 \%$ PCL and $\mathrm{PCL}-\mathrm{CeO}_{2}$ with surfactant at concentrations of $\mathrm{CeO}_{2}: 0.25,0.5,1,1.5 \%(\alpha=0.05)$. Figure 10 resumes the behavior of the DNA tail moment of the nuclei of $V$. faba in error bars with a $95 \%$ confidence interval. Fibers of $10 \%$ with $\mathrm{CeO}_{2}$ particles at different concentrations $(0.25,0.5,1$ and $1.5 \%)$ present low DNA damage of $V$. faba nuclei, the damage is considered non-significant as the tail moment was between 0 to $26 \mu \mathrm{m}^{[21]}$.

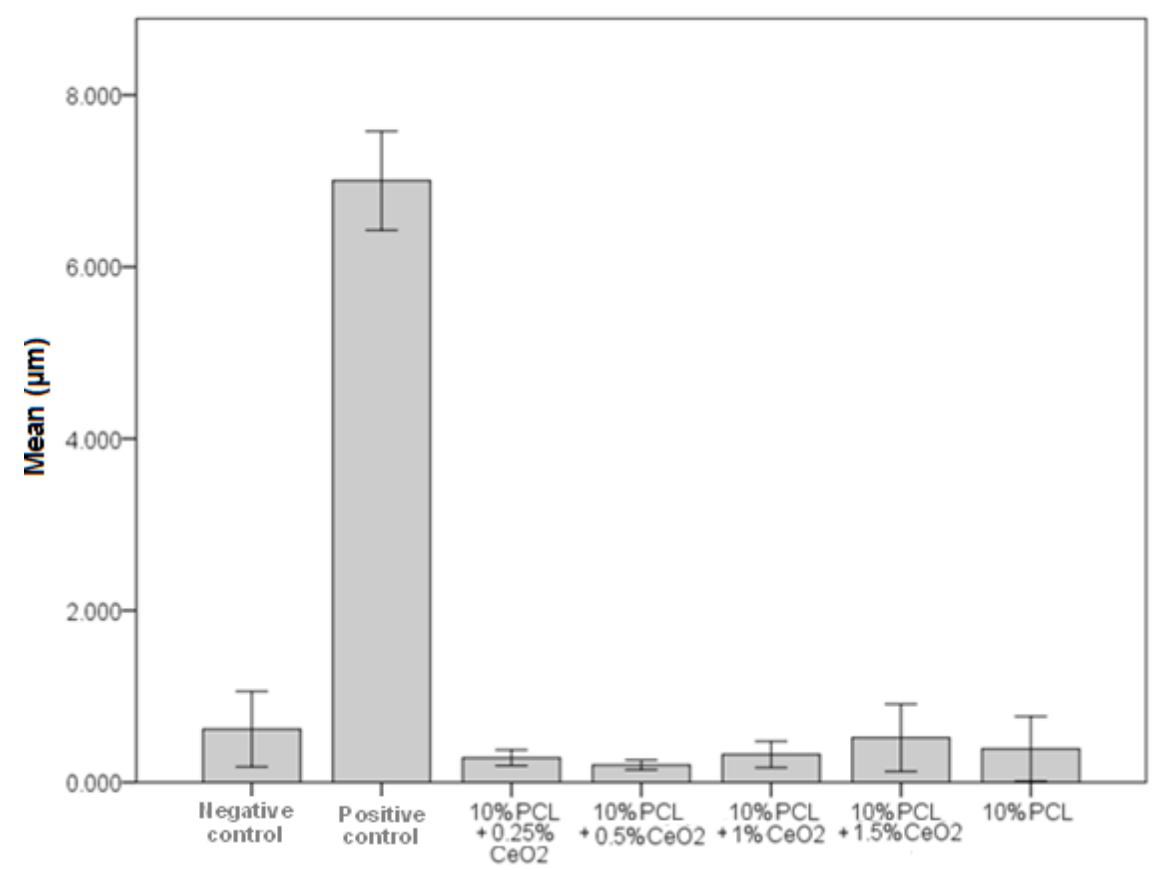

Figure 10: Tail moment in nuclei of cells of Vicia faba of the different treatments.

\section{Conclusions \& Recommendations}

A PCL-CeO $\mathrm{C}_{2}$ composite material was produced. PCL-CeO $\mathrm{C}_{2}$ fibers were obtained by the electrospinning technique controlling the parameters: temperature, humidity, voltage and distance. A smaller diameter $(0.66 \mathrm{um})$ was obtained using a distance of $14 \mathrm{~cm}$, a flow of 15 $\mu \mathrm{L} / \mathrm{m}$, a humidity of $16 \%$, a temperature of $19^{\circ} \mathrm{C}$. The $\mathrm{PCL}-\mathrm{CeO}_{2}$ composite with a $\mathrm{CeO}_{2}$ concentration of $0.25 \%$ and surfactant showed a homogeneous distribution of the cerium particles, fibers had $0.8 \mu \mathrm{m}$ diameter. Infrared spectroscopy, confocal and electron microscopy techniques verify the existence of $\mathrm{CeO}_{2}$ particles within the PCL fibers. The thermal analysis of the PCL-CeO2 composite demonstrates the phase transitions of the polymer and at $475^{\circ} \mathrm{C}$ the 
organic material of the polymer is completely lost, leaving only the corresponding percentage of the ceria particles. The genotoxic study of the $\mathrm{PCL}-\mathrm{CeO}_{2}$ composite by single cell gel electrophoresis assay showed that the material has no genotoxic effects on Vicia faba cells.

\section{Acknowledgements}

Authors gratefully acknowledge financial support by CONACYT and PROMEP. S. Reyes-Lopez thanks Dr. Carlos Rodriguez for SEM images.

\section{Conflict of interests}

The authors declare that there is no conflict of interests regarding the publication of this paper.

\section{References}

[1] Fang, J., Wang, X., \& Lin, T. (2011). Functional applications of electrospun nanofibers, Nanofibers-Production, Properties and Functional Applications. In Nanofibers-production, properties and functional applications. InTech. 1-458.

[2] López-Esparza, J., Espinosa-Cristóbal, L. F., Donohue-Cornejo, A., \& Reyes-López, S. Y. (2016). Antimicrobial activity of silver nanoparticles in polycaprolactone nanofibers against gram-positive and gram-negative bacteria. Industrial \& Engineering Chemistry Research, 55(49), 12532-12538.

[3] Garibay-Alvarado, J. A., Espinosa-Cristóbal, L. F., \& Yobanny, S. Fibrpus Silica/Hydroxyapatite Composite by Electrospinning.

[4] Frenot, A. y Chronakis, I.S. 2003. Polymer nanofibers assembled by electrospinning. ELSEVIER. 8:64-75.

[5] Lord, M. S.; Tsoi, B.; Gunawan, C.; Yang, W.; Amal, R. y Whitelock, M. 2013. Anti-angiogenic activity of heparin functionalized cerium oxide nanoparticles. Biomaterials. 34: 8808-8818.

[6] R. Nirmala, H. S. Kang, H. M. Park, R. Navamathavan, I. S. Jeong, H. Y. Kim, Silver-loaded biomimetic hydroxyapatite grafted poly ( $\varepsilon$-caprolactone) composite nanofibers: a cytotoxicity study, J. Biomed. Nanotechnol. 8 (2012) 125-132.

[7] S. Y. Reyes López, D. Cornejo Monroy, G. González García, A novel route for the preparation of gold nanoparticles in polycaprolactone nanofibers, J. Nanomater. (2015).

[8] J. H. Roque-Ruiz, E. A. Cabrera-Ontiveros, J. Torres Pérez, S. Y. Reyes-López, Preparation of PCL/Clay and PVA/Clay electrospun fibers for Cadmium $(\mathrm{Cd}+2)$, Chromium $(\mathrm{Cr}+3)$, Copper $(\mathrm{Cu}+2)$ and Lead $(\mathrm{Pb}+2)$ removal from water, Water Air Soil Pollut. 227:286 (2016) 1-17.

[9] Collins, A, R. 2004. The comet assay for DNA damage and repair. Molecular biotechnology. 26(3): 249-261.

[10] Liao, W.; McNutt, M. A.; Zhu, W. 2009. The comet assay: A sensitive method for detecting DNA damage in individual cells Methods. 48(1): 46-53.

[11] Ramírez, R. P.; Mendoza, C. A. Ensayos toxicológicos para la evaluación de sustancias químicas en agua y suelo. Secretaria de Medio ambiente y Recursos Naturales (SEMARNAT). México. 2008. 235-236p.

[12] Gichner, T. 2003. Comet Assay in higher plants. Bioassays in plant Cells for Improvemente of Ecosystem and Human Health. Katowice: Wydawnictwo Uniwersytetu Śląskiego, 123-131.

[13] Hernández, E. J.; Silva, R. R.; García A. R.; García, A. A.; Edward, H. B.; Cárdenas, G. G. y Cueto, H. A. 2012. Synthesis and Physico-chemical Characterization of CeO2/ZrO2-SO4. J. Mex. Chem. Soc. 56(2): 115-120. 
[14] CIAT. Los surfractantes: Clases, propiedades y uso con herbicidas. Edit. XYZ. Colombia. 1980. $48 \mathrm{p}$.

[15] Sill, T.; Horst, A. y Recum, V. 2008. Review electrospinning: Application in drug delivery and tissue engineering. ScienceDirect. 29(13): 1989-2006.

[16] Moreno, B. R. Reología de suspensiones cerámicas. Edit. CSIC. España. 2005. 325p.

[17] Salager, J.; Anton, R. Métodos de medición de la tensión superficial o interfacial. Edit. FRP. Mérida. 2005. 20p.

[18] Ansari, A. A. 2010. Optical and structural properties of sol-gel derived nanostructured $\mathrm{CeO} 2$. Journal of semiconductors. 31(5): 1-5.

[19] Ghasemi, M. L.; Prabhakaran, P. M.; Morshed, M.; Hossein, N. M. y Ramakrishna, S. 2010 Biofunctionalized PCL nanofibrous scaffolds for nerve tissue engineering. Materials Science and Engineering C. 30(8): 1129-1136.

[20] Leilei, X.; Huanling, S.; Lingjun, Ch. 2012. Mesoporous nanocrystalline ceria-zirconia solid solutions supported nickel based catalysts for CO2 reforming of CH4. SciVerse ScienceDirect. 37 (23): 18001-18020.

[21] Garcia, H. P.; Pabón, A.; Arias, C.; Blair, S. 2013. Evaluación del efecto citotóxico y del daño genético de extractos estandarizados de Solanum nudum con actividad anti-Plasmodium. 33 (1): 78-87.

*Corresponding author.

E-mail address: simon.reyes@ uacj.mx 